\title{
Month-of-the-Year Effect: Empirical Evidence from Indian Stock Market
}

\author{
Rajesh Elangovan ${ }^{1} \cdot$ Francis Gnanasekar Irudayasamy ${ }^{2}$. \\ Satyanarayana Parayitam ${ }^{3}$ D
}

Accepted: 9 December 2021 / Published online: 8 January 2022

(c) The Author(s), under exclusive licence to Springer Japan KK, part of Springer Nature 2022

\begin{abstract}
The present study aims to examine the existence of month-of-the-year effects in the Indian stock market. For analysis, we selected the BSE Ltd and NSE broad market cap indices, namely S\&P BSE 500 and NIFTY 500, which are a comprehensive representation of the Indian stock market. The time selected for this study is from April 1, 2011, to March 31, 2021 (i.e., ten years). The study used secondary data collected from the 'monthly open, high, low and closing prices of broad market indices of the Indian stock market through the official websites (www.bseindia.com; and www. nseindia.com). The study's findings indicate that the ADF and PP test confirms the presence of unit root of the return series of S\&P BSE 500 and NIFTY 500 Indices. The results from the KPSS test confirm the stationarity of the return series of both Indices. The regression coefficients for March were negative and significant for both indices. These results suggest that the month-the-of-the-year effect is the 'March effect.'
\end{abstract}

Keywords Calendar anomalies · Month-of-the-year effect · KPSS test · ARIMA and GARCH

Satyanarayana Parayitam

sparayitam@umassd.edu

Rajesh Elangovan

rajeshthami1654@gmail.com

Francis Gnanasekar Irudayasamy

francis_sekar@rediffmail.com

1 Department of Commerce, Bishop Heber College (Autonomous), Tiruchirappalli, India

2 Department of Commerce, St. Joseph's College (Autonomous), Tiruchirappalli, India

3 Department of Management and Marketing, Charlton College of Business, University of Massachusetts Dartmouth, 285 Old Westport Road, North Dartmouth, MA 02747, US 


\section{Introduction}

The humorous comment by Mark Twain implies that speculation has no place in stock markets, and there is no good time to speculate. One of the heavily debated topics in finance and economics is the efficient market hypothesis (EMH) which states that stock prices reflect all the available information (Fama, 1970) Therefore, investors can't enjoy abnormal returns than the market rate of return. If stock markets are efficient, the market capitalization represents the firm's fair value, i.e., future cash flows discounted by the cost of capital. The EMH is built on two assumptions: (i) all available information is fully incorporated into the stock prices, and (ii) investors would not be in a position to earn a risk-weighted excess return than the market return. In the weak form, market efficiency does not yield any excess return. In semi-strongly efficient markets, the current stock prices reflect historical information. Still, they include the information which is currently available (for example, announcements of mergers, dividend pay-outs, changes in the top management team members, etc.). In the strong form of efficient markets, current stock prices reflect all available, including insider information, in addition to the publicly available information. Therefore, in a strong form of market efficiency, researchers contend that it is impossible to earn excess profits relying on insider information (Malkiel, 2003).

Fluctuations in stock prices challenge EMH due to calendar anomalies, and researchers in finance and economics documented the effect of these anomalies. Changes in calendar effects have been on the research agenda for the last four decades. Researchers identified three types of anomalies seasonal, technical, and fundamental anomalies that significantly affect stock returns (Srinivasan \& Kalaivani, 2013). A plethora of research is available on the day-of-the-week effect, weekly effect, weekend effect, month-of-the year effect, semi-month effect, turnof-the-month effect, holiday effect, Ramadan effect, Diwali effect, Independence Day effect (July 4th in the USA), Halloween effect, etc., (Agrawal \& Tandon, 1994; Barone, 1990; Compton et al., 2013; Haroon \& Shah, 2013; Harshita et al., 2018; Patel \& Sewell, 2015). Digging up literature, one can find that some studies provided strong support for the seasonal fluctuations (e.g., Easterday et al., 2009). On the other hand, some did not support evidence for seasonality in stock prices (Cheung \& Coutts, 1999; Zinbarg \& Harrington, 1964). Some critics argue that the data might have been tortured until it confessed (Merton, 1987).

The objective of the present study is to test the presence or absence of the month-of-the-year effect in the Indian stock market. Several studies in the past have documented that returns on financial assets exhibited systematic patterns at certain calendar months so that investors can benefit from these seasonal variations (Brooks, 2019; Jacobs \& Levy, 1988). The financial year in India runs from April to March, and extant research supported effects in January and November (see Table 1 for pieces of evidence from previous studies conducted in India). The study period covered transition of political power in India in 2014, thus necessitates study of stock market anomalies. We organize the paper as follows. First, we present the literature review in Sect. 2, followed by data and methodology in 


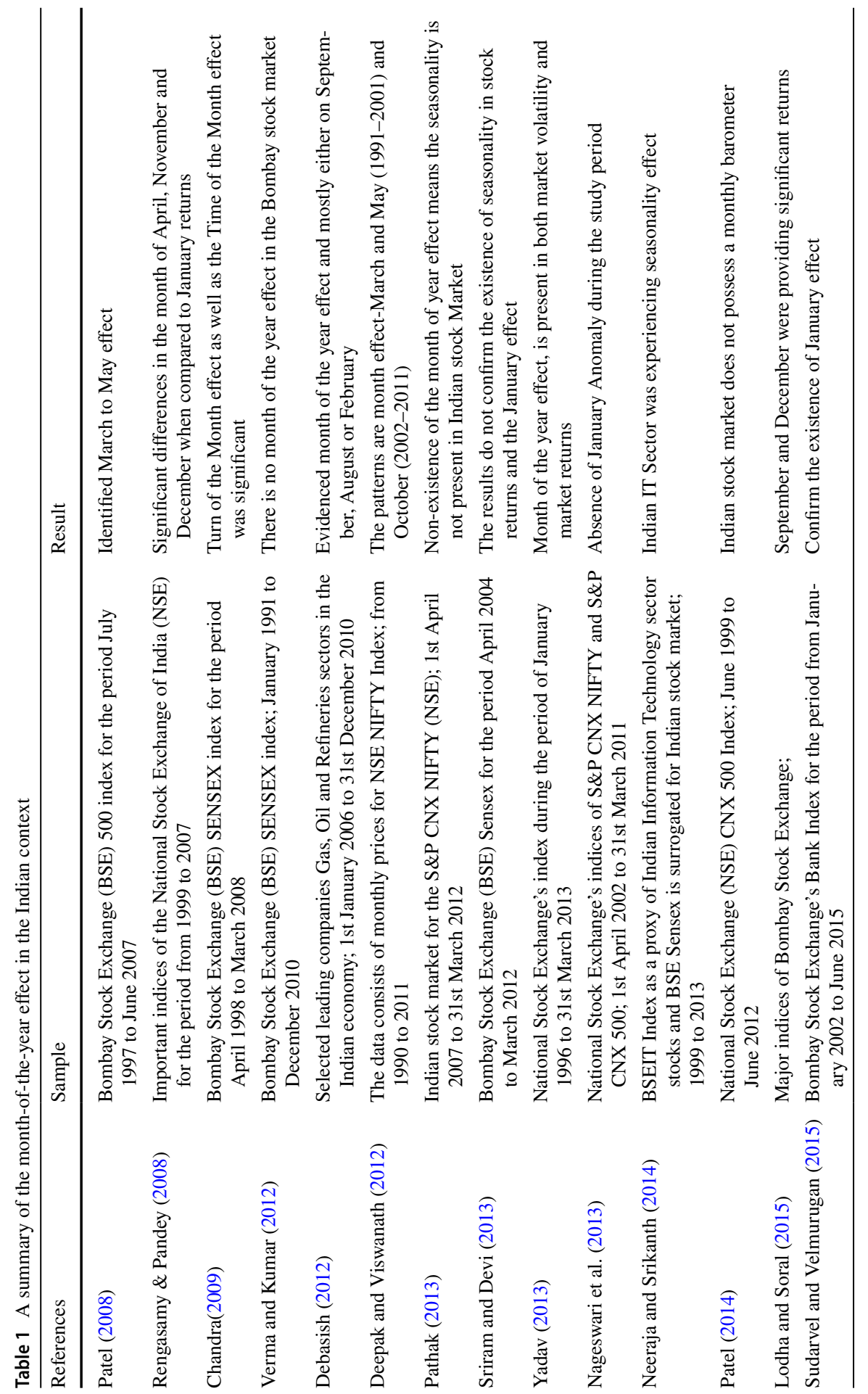




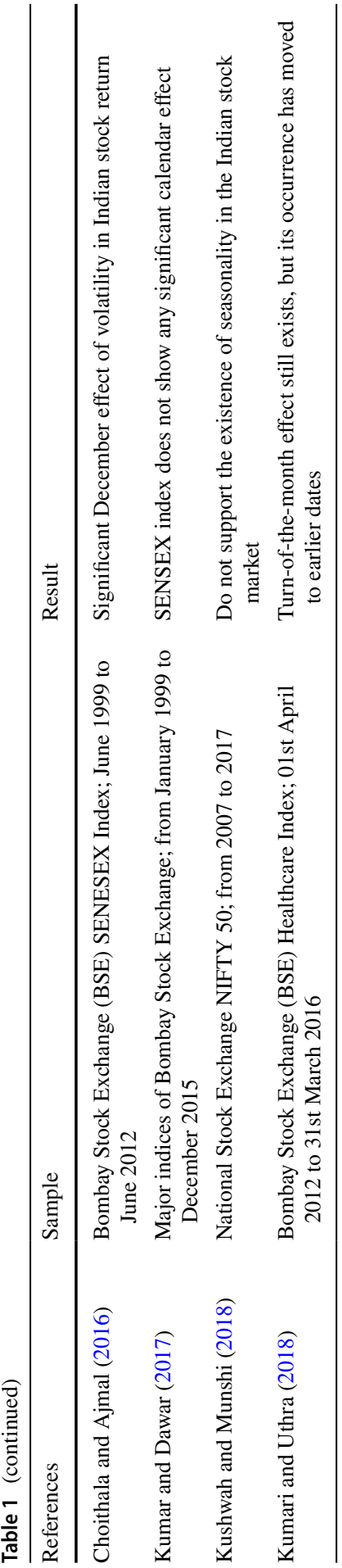


Sect. 3. We offer the analysis and findings in Sect. 4 and discussion and managerial implications in the final section.

\section{Literature Review}

While the historical evidence on the seasonality of stock market returns provided by Fields (1931) and Wachtel (1942), systematic analysis of stock market anomalies started with Cross (1973), followed by French (1980). History is replete with studies that focused on day-of-the-week effect, weekly effect, weekend effect, month-of-theyear effect, semi-month effect, turn-of-the-month effect, and holiday effect. Unfortunately, the results are inconclusive and inconsistent. Since our objective in the present research is to examine the month-of-the-year impact empirically, we found that most of the studies documented the January effect (Aggarwal \& Rivoli, 1989; Agrawal \& Tandon, 1994; Asteriou \& Kavetsos, 2006; Beyer et al., 2013; Floros, 2011; Pettengill, 1986; Wilson \& Jones, 1993).

One of the classic studies that analyzed data from 1904 to 1974 in the US stock market, Rozeff and Kinney (1976), showed that the returns in January were significantly higher than in the other eleven months. High returns in January were labelled as 'month-of-the-year effect,' and subsequent research conducted on seventeen countries, the January effect was significant in thirteen countries (Gultekin \& Gultekin, 1983). The January effect was explained by Brown et al. (1983) as the tax-loss selling hypothesis according to which investors are motivated to sell stock at the end of the year to get tax benefits. Therefore the prices get depressed and then bounce back in January. This was supported because, in 1917, there was no January effect. After all, there was no tax incentive (Schultz, 1985), which made the January hypothesis strong. The subsequent researchers also supported the tax-loss selling hypothesis for the January effect (Chen \& Singal, 2003). However, some researchers argue that the tax-loss selling hypothesis was true before the Federal income taxes (Berges et al., 1984; Jones et al., 1991), and the January effect was insignificant.

A plethora of researches has been done concerning the month-year-of-the-year effect in both international markets and the Indian stock market. There is a diversity of results, and there is no unanimity in finding out the month-of-the-year effect. In the US, Denmark, France, Germany, Norway, Sin/Mal, Spain, Switzerland, and Malaysia, the January effect found support from several researchers (Boudreaux, 1995; Keim, 1983; Wong et al., 2007). The January effect was not found in the New Zealand stock market (Li \& Liu, 2010), In the Chinese market, while Gao and Kling (2005) found support for March and April effects, whereas Luo et al. (2009) did not find any month-of-the-year effects. In a study by Silva (2010), the January effect was not found in the Portuguese stock market. The July effect was found in Ghana (Albert et al., 2013), December was the best month in the Indonesian stock market (Rahario et al., 2013).

Regarding literature review concerning the stock market in India, March to May effect was found by Patel (2008), April, November, and December effects were found by Rengasamy \& Pandey (2008), Diwali effect was found in Harshita et al. (2018). Moreover, some researchers found significant results during September and 
December (Lodha, 2015). On the contrary, some studies did not find any monthof-the-year effect (Verma \& Kumar, 2012; Sairam \& Devi, 2013; Patel, 2014). The summary of previous studies conducted in the Indian and international stock markets is presented in Tables 1 and 2.

\subsection{Rationale for the Present Study}

After going over the literature review, one may question why another study? The rationale for the present study stems from three reasons: First, the literature review reveals that different scholars have focused on different years to study the month-of-the-year effect. For example, Patel (2008) studied the Bombay Stock Exchange (BSE) 500 index during 1997-2007; Verma and Kumar (2012) studied BSE SENSEX during 1998-2008, and Kushwah and Munshi (2018) have studied National Stock Exchange (NSE) NIFTY 500 from 2007-2017. Likewise, several researchers in the past studied BSE, NSE during different periods. The present study explores BSE 500 and NIFTY 500 indices during the last decade (2011-2021). Our study extends growing literature on stock market returns concerning the month-ofthe-year effect. The other studies conducted in the Indian context were presented in Table 1, and the reflections in the non-Indian context are shown in Table 2.

Second, the rationale for the present study is because of the diversity of results from previous studies, as documented in Tables 1 and 2. For example, while some studies found the March to May effect, others found the September and December effects. Now, during this current period, we wanted to explore what was regarded as the month-of-the-year effect.

Third, researchers have been trying to find if there is any possibility for the investors to secure an above-average rate of returns (example, January effect, April effect, November effect, etc.). In simple words, the month-of-the-year effect refers to the identification of month (or months) in a calendar year that gives statistically significant abnormal returns. The term month of the year effect implies that among the month of the year, i.e., (January to December), any one of the months gives statistically significant abnormal returns. Therefore, to earn an abnormal return, the investors have to frame the trading strategies called seasonal anomalies viz., day of the week effect, the month of the year effect, monthly effect, holiday effect, and quarter of the year effect. The present study focuses on identifying the month-of-the-year effect in the Indian stock market.

\subsection{Objectives of the Study}

The study's primary objective is to examine the existence of the month-of-the-year effect in Indian Stock Markets. The primary objective is split into the following sub-objectives:

(1) To empirically examine the month-of-the-year effect from 1st April 2011 to 31st March 2021 in India. 


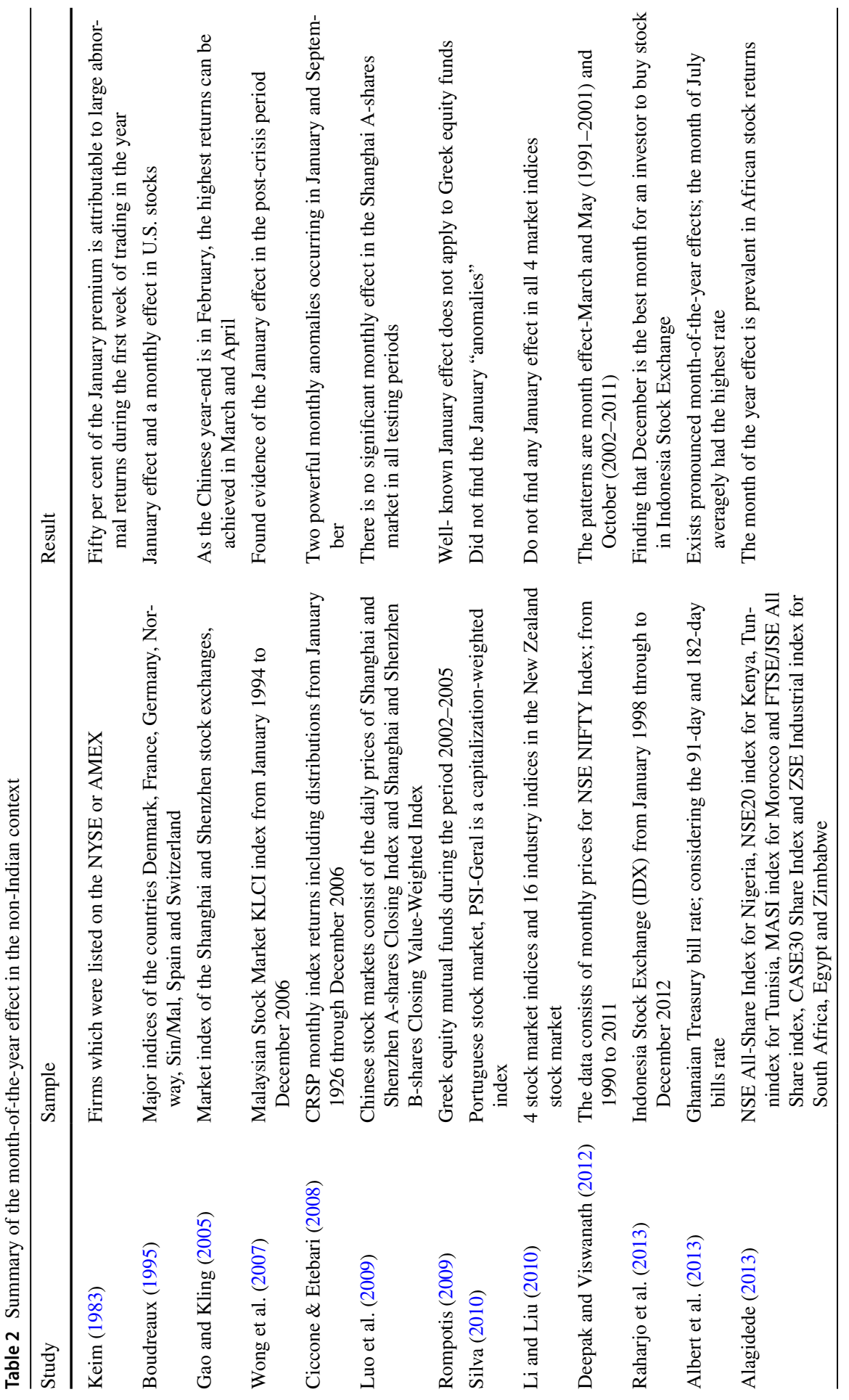




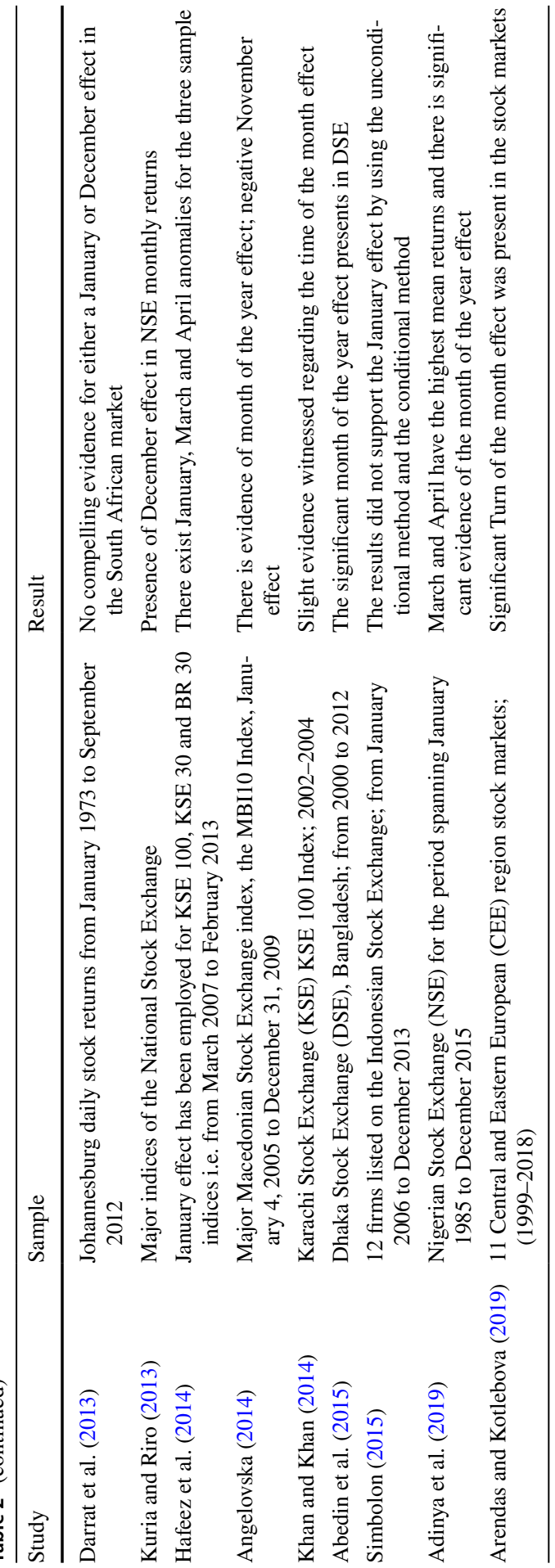


(2) To explain the reasons for the month-of-the-year effect and suggest to investors the consequences of the month-of-the-year impact in India.

(3) To provide directions for future research concerning the month-of-the-year effect in the Indian context.

To study the month-of-the-year effect, we need to examine whether monthly return series of the indices are stationary or not. We also need to examine the descriptive statistics for S\&P BSE 500 and NIFTY 500 indices for the month of the year. Thirdly, it is essential to examine whether the stock market indices follow a normal distribution. To achieve these, the following hypotheses are formulated.

\section{Hypothesis}

Since the objective of the present study is to empirically examine the month-of-theyear effect in the Indian stock market, the following hypothesis is formulated:

HO (Null Hypothesis): In Indian stock market, there is no month-of-the-year effect.

$H 1$ (Alternate hypothesis): In Indian stock market, there is month-of-the-year effect.

The sub-hypotheses to test the above main hypothesis are:

$H_{01}$ : The series has a unit root

$H_{02}$ : The series is stationary

$H_{03}$ : The monthly mean returns are statistically equal across the trading month of the year

\section{Methodology}

In this research, we started with the identification of the problem, outlined the study's objectives and hypotheses, selected the sample and collected the data, selected the right econometric tools to analyze the data, and presented the results. The methodology is mentioned in the flowchart (Fig. 1).

\subsection{Sample}

In India, the two leading recognized stock exchanges, viz., the BSE Ltd and NSE, play a vital role in the growth of the Indian economy. Hence, most researchers consider these two-stock exchange's market cap indices, namely S\&P BSE 500 and NIFTY 500. The sample included for the study is from 1st April 2011 to 31st March 2021, which consists of 10 years. 


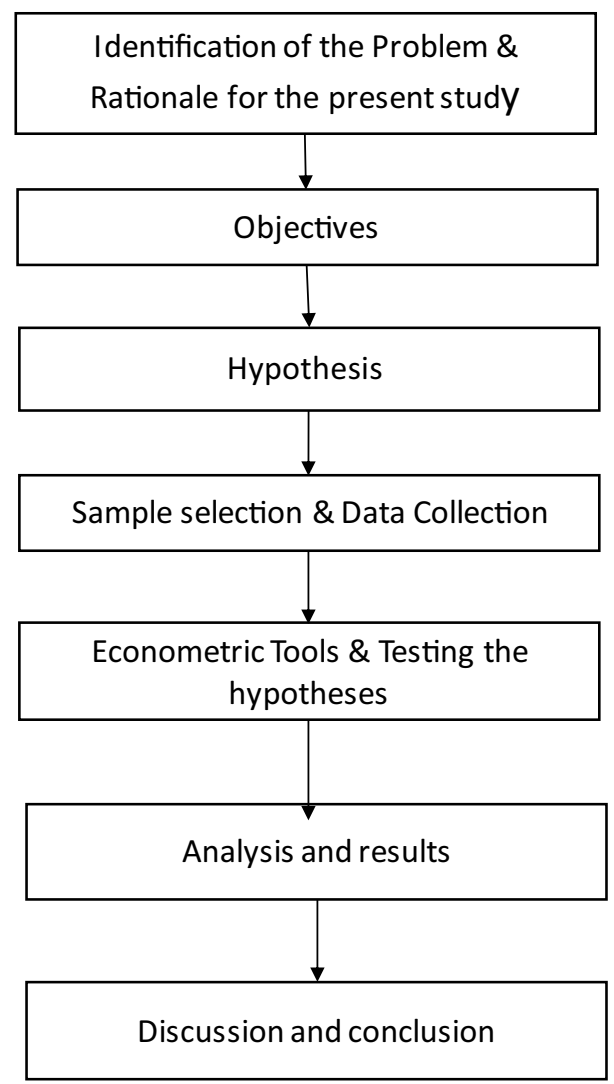

\subsection{Data Collection}

The present empirical study was mainly based on the secondary data collected from the official websites of the Bombay Stock Exchange (i.e., www.bseindia.com) and the National Stock Exchange (i.e., www.nseindia.com). The data collected for this study included: 'monthly open,' 'high,' 'low,' and 'closing prices' of market cap indices of the Indian Stock Market. It should be noted that NSE does not provide monthly open, high, low, and closing prices. Instead, NSE provides daily open, high, low, and closing prices, and hence we took the prices on the first day of every month. The monthly returns are calculated on the basis of average price. While prior researchers have used only closing prices as if the trading is done at the closing price, Lodha and Soral (2015) recommended using the simple arithmetic mean of the four prices. The underlying logic is that by considering the average price the volatility of prices can be controlled to some extent. We used the following formulae for the returns: 


$$
r_{t}=\ln \left(p_{t} / p_{t-1}\right) * 100
$$

where $r_{t}$ is the return at the time $t$, $\ln$ represents natural $\log , p_{t}$ and $p_{t-1}$ are closing prices at time $t$ and $t-1$ respectively. If the returns series is detected to be stationary, the analysis is supposed to be performed on the stationary series. As we recall the fundamentals, a series is said to be stationary only if has (a) a constant mean ( $\mu$ ), (ii) a constant variance $\left(\sigma^{2}\right)$, and (iii) a constant covariance structure $\left(\gamma_{\mathrm{s}}\right)$. Though there are two types of stationarity (viz., deterministic, stochastic). When the series has a linear trend making it non-stationary, it is called a deterministic non-stationarity series. It should, however, be noted that if the series is stationary around that trend, it is called trend-stationary series (Brooks, 2019). In financial economics, time series in general exhibit stochastic non-stationarity, if not stationarity.

\subsection{Econometric Tools used in the Study}

For analysing the data, we used Eviews-7. The econometric tools used in this study are:

(i) Augmented Dickey-Fuller (ADF) test and Phillips-Perron (PP) tests to detect the unit root of the monthly return series; PP test is used to adjust possible autocorrelation in the residuals

(ii) Kwiatkowski-Phillips-Schmidt-Shin (KPSS) test and correlogram to verify the stationarity of monthly return series; KPSS test serves as a confirmatory data analysis. One should note that while ADF and PP tests have null hypotheses that unit root is present in the series, the null hypothesis in KPSS is that the series is stationary

(iii) Regression for examining the month of the year effect by considering all twelve months in a year. The following regression equation used to find the month of the year effect

$$
\begin{aligned}
Y t= & \alpha_{1}+\alpha_{2 D} F e b+\alpha_{3 D} \text { Mar }+\alpha_{4 D} A p r+\alpha_{5 D} \text { May }+\alpha_{6 D} J u n+\alpha_{7 D} J u l \\
& +\alpha_{8 D} A u g+\alpha_{9 D} \text { Sep }+\alpha_{10 D} \text { Oct }+\alpha_{11 D} \text { Nov }+\alpha_{12 D} \text { Dec }+\varepsilon_{1}
\end{aligned}
$$

where, the constant term $\left(\alpha_{1}\right)$ is the average mean return for the January trading month, and coefficients $\alpha_{2}$ to $\alpha_{12}$ denotes the average differences between the return from February trading month to December trading month, except for January. If the value of the coefficients of $\alpha_{2}$ to $\alpha_{12}$ is zero, then the return for each month of the year is identical and no evidence of month-of-the-year effect exists. and $\varepsilon_{1}$ represents the white noise error term.

(iv) ARIMA model to remove the persistence of serial correlation

(v) GARCH model to remove the heteroskedasticity effect. 


\section{Results}

The Unit root test and stationarity test results for monthly closing prices and monthly returns of S\&P BSE 500 and NIFTY 500 Indices return series were presented in Table 3.

As can be seen in the Intercept of ADF test statistics of the closing price of S\&P BSE $500(0.380)$ and NIFTY 500 (0.357) is greater than their critical values of 1 percent, 5 percent, and 10 percent levels of insignificant respectively (the values were given in parenthesis). Hence, $\mathrm{HO}$ (the series has a unit root) is not rejected (following the ADF test). Likewise, the Intercept of PP test statistics of the closing price of S\&P BSE 500 (0.498) and NIFTY 500 (0.457) is greater than their critical values of 1 percent, 5 percent, and 10 percent levels of insignificant respectively (the values were given in open parenthesis). Hence, $H O$ (the series has a unit root) is not rejected (following the PP test). Finally, the KPSS test statistic (1.261) of the closing price of S\&P BSE 500 and NIFTY 500 is greater than the critical value at a $1 \%$ significance level (0.739), rejects the null hypothesis of a stationary series. Hence, $H O$ (the series is stationary) is rejected (following the KPSS test).

The Intercept of ADF test statistics of return series of S\&P BSE 500 (-7.588) and NIFTY $500(-7.641)$ is less than their critical values of 1 percent, 5 percent and 10 percent levels of significance respectively (the values were given in parenthesis). Hence, $H_{0}$ (the series has a unit root) is rejected (following the ADF test). The Intercept of PP test statistics of return series of S\&P BSE $500(-6.484)$ and NIFTY $500(-6.454)$ is less than their critical values of 1 percent, 5 percent and 10 percent levels of significance respectively (the values were given in parenthesis). Hence, $H_{0}$

Table 3 Unit root test and stationarity test for monthly closing prices and monthly returns. Source: Compiled from Eviews7

\begin{tabular}{lllll}
\hline Index & Test & Test statistic & $p$ value & Comment \\
\hline \multirow{4}{*}{ S\&P BSE 500 } & Closing prices & & & \\
& ADF Test & $0.380(-3.487)(-2.886)(-2.580)$ & 0.981 & Ho: not rejected \\
& PP test & $0.498(-3.486)(-2.886)(-2.580)$ & 0.986 & Ho: not rejected \\
& KPSS Test & $1.262(0.739)(0.463)(0.347)$ & 0.000 & Ho: rejected \\
NIFTY 500 & ADF Test & $0.357(-3.487)(-2.886)(-2.580)$ & 0.980 & Ho: not rejected \\
& PP test & $0.457(-3.486)(-2.886)(-2.580)$ & 0.985 & Ho: not rejected \\
& KPSS Test & $1.261(0.739)(0.463)(0.347)$ & 0.000 & Ho: rejected \\
& Returns & & & \\
S\&P BSE 500 & ADF Test & $-7.588(-3.487)(-2.886)(-2.580)$ & 0.000 & Ho: rejected \\
& PP test & $-6.484(-3.487)(-2.886)(-2.580)$ & 0.000 & Ho: rejected \\
& KPSS Test & $0.070(0.216)(0.146)(0.119)$ & 0.808 & Ho: not rejected \\
NIFTY 500 & ADF Test & $-7.641(-3.487)(-2.886)(-2.580)$ & 0.000 & Ho: rejected \\
& PP test & $-6.454(-3.487)(-2.886)(-2.580)$ & 0.000 & Ho: rejected \\
& KPSS Test & $0.070(0.216)(0.146)(0.119)$ & 0.758 & Ho: not rejected
\end{tabular}

ADF Test $H_{0}$ : the series has a unit root; PP Test: $H_{0}$ : the series has a unit root; KPSS Test: $H_{0}$ : the series is stationary 
(the series has a unit root) is rejected (following the PP test). Therefore, it could be interpreted that the ADF and PP test confirms the unit root of the return series of S\&P BSE 500 and NSE NIFTY 500 Indices. The p-value of the KPSS test of return series of S\&P BSE 500 (0.808) and NIFTY 500 (0.758) is greater than the significance level of (0.05). Hence, $H_{0}$ (the series is stationary) is not rejected. KPSS test confirms the stationarity of the return series of both Indices.

The confirmatory data analysis revealed that (i) the monthly closing prices series is not stationary, and (ii) the returns series exhibit stationarity. These findings are consistent with the results from the previous studies in the literature on finance, adding to the growing body of literature. The graphical representation of these two series over time are presented in Figs. 2 and 3.

As can be seen in the Figs. 2 and 3, the closing share price is non-stationarity because it is continuously changing in the line graph.

The graphs of the return series of S\&P BSE 500 and NIFTY 500 indices were presented in Figs. 4 and 5.

The figures indicate that indices are fluctuating between high and low, and the proportions of deviation are different at different time periods of the study, but they return to their respective means. It is not surprising to find that during the year 2020, both indices of the graph line showed high volatility because of the impact of Covid19 global pandemic. It is understood that both indices have constant mean returns over the period and the mean values lie on 0 . It can be interpreted that both indices are stationarity in nature.

The descriptive statistics of monthly returns of S\&P BSE 500 and NIFTY 500 indices were shown in Figs. 6 and 7.

As can be seen in Fig. 6, descriptive statistics of monthly returns of S\&P BSE 500 report a kurtosis of 7.142. Since the value is greater than 3, the returns series

\section{Monthly closing price of S\&P BSE 500}

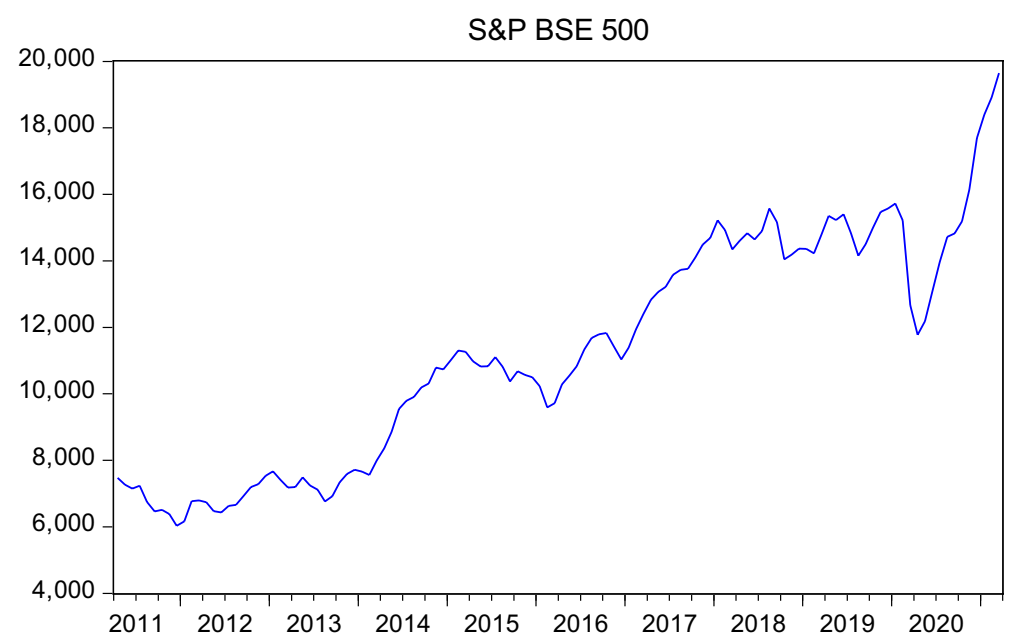

Fig. 2 Monthly closing price of S\&P BSE 500. Source: Compiled from Eviews7 


\section{Monthly closing price of NIFTY 500}

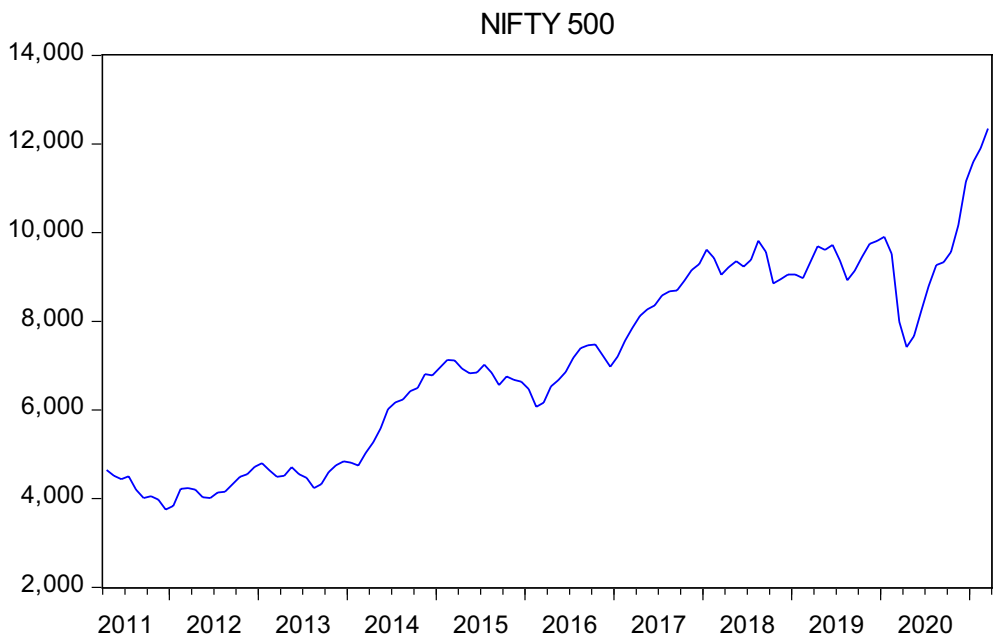

Fig. 3 Monthly closing price of NIFTY 500. Source: Compiled from Eviews7

Monthly return series of S\&P BSE 500

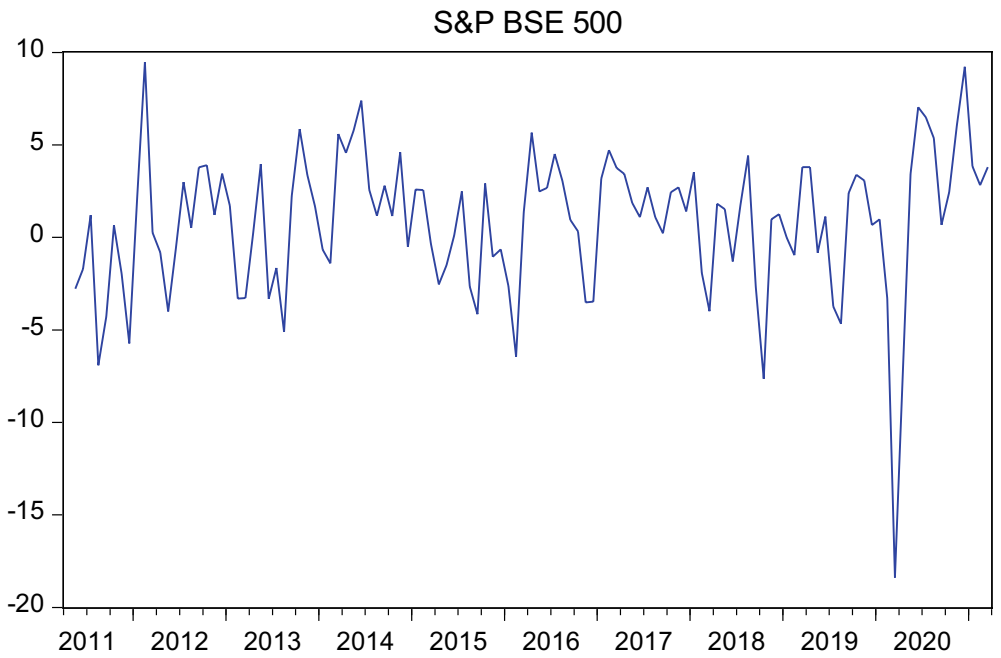

Fig. 4 Monthly return series of S\&P BSE 500. Source: Compiled from Eviews7

is leptokurtic (Brooks, 2019). The descriptive statistics presented in Fig. 7 for the monthly returns of NIFTY 500 show the kurtosis of 6.3707 reveal that the returns series is leptokurtic as the value is greater than 3 (Brooks, 2019).

Kurtosis represents the possibility of the stock prices to fluctuate significantly and hence is very important from investors' point of view. The shape of distribution 


\section{Monthly return series of NIFTY 500}

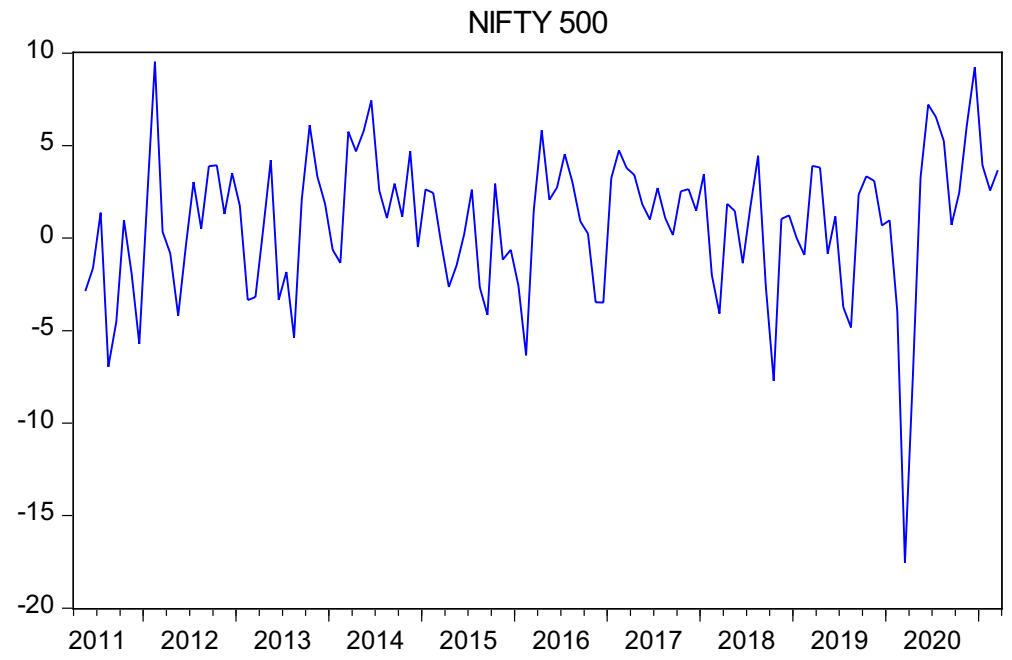

Fig. 5 Monthly return series of NIFTY 500. Source: Compiled from Eviews7

Histogram and descriptive statistics of monthly returns of S\&P BSE 500

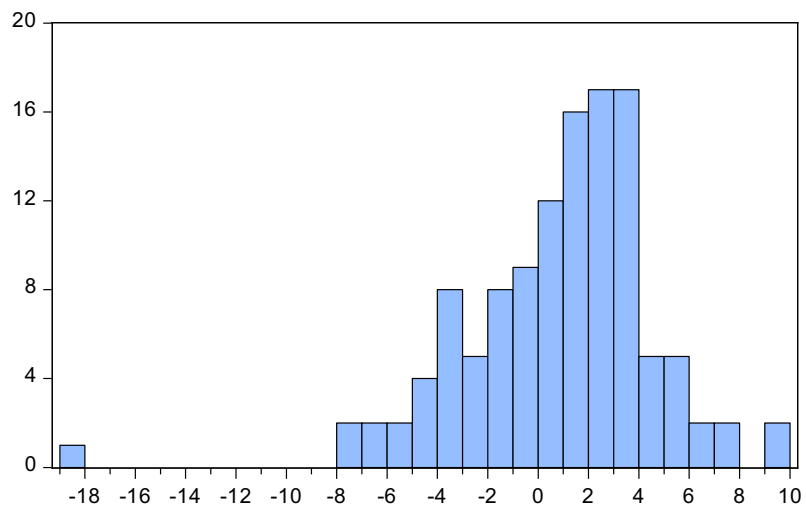

Series: RETURN

Sample 2011M04 2021M03

Observations 119

Mean $\quad 0.812281$

Median $\quad 1.217785$

Maximum $\quad 9.468050$

Minimum $\quad-18.37977$

Std. Dev. $\quad 3.840088$

Skewness $\quad-1.149815$

Kurtosis $\quad 7.142062$

Jarque-Bera $\quad 111.2897$

Probability $\quad 0.000000$

Fig. 6 Histogram and descriptive statistics of monthly returns of S\&P BSE 500. Source: Compiled from Eviews7

explains whether the stocks are pricing risky assets by looking at the distribution and volatility of the prices (Ivanovski et al., 2015). The results indicate that significant variations in daily prices are noticeable than those estimated by normal distribution. The leptokurtic distribution, representing the excessive positive kurtosis, suggests that risk-seeking investors experience fluctuations resulting in substantially high or low returns. Sometimes, the investors make maximum profits when returns are very high and sometimes they also suffer losses when the returns are low. 
Histogram and descriptive statistics of monthly returns of NIFTY 500

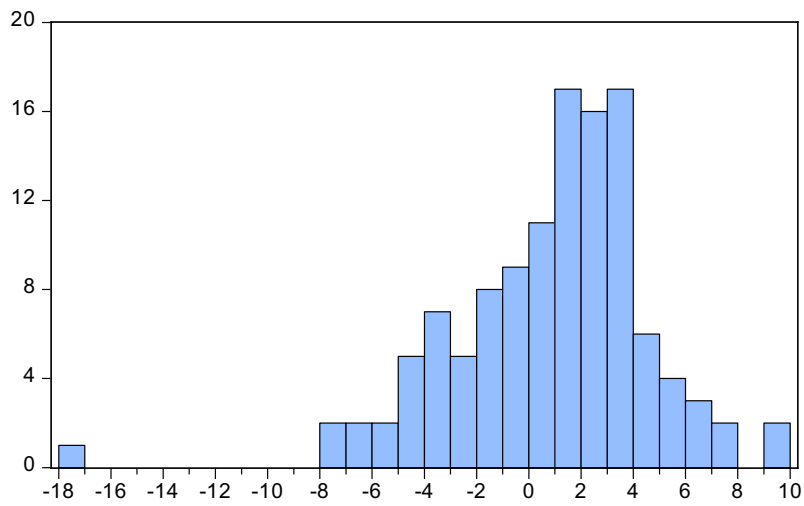

\begin{tabular}{|c|c|}
\hline \multicolumn{2}{|c|}{$\begin{array}{l}\text { Series: RETURN } \\
\text { Sample 2011M04 2021M03 } \\
\text { Observations } 119\end{array}$} \\
\hline Mean & 0.821562 \\
\hline Median & 1.299626 \\
\hline Maximum & 9.528234 \\
\hline Minimum & -17.55741 \\
\hline Std. Dev. & 3.841922 \\
\hline Skewness & -1.033960 \\
\hline Kurtosis & 6.370748 \\
\hline Jarque-Bera & 77.53961 \\
\hline Probability & 0.000000 \\
\hline
\end{tabular}

Fig. 7 Histogram and descriptive statistics of monthly returns of NIFTY 500. Source: Compiled from Eviews7

The Correlogram analysis was done and the results were shown in Tables 4 and 5.

The autocorrelation function did not show large spikes at lag 1 and autocorrelation hurriedly fall from 0.420 to -0.046 for S\&P BSE 500 and 0.422 to -0.050 for NIFTY 500, when the lag length increased. The ACF after the lag 1 to lag 16 coefficients values of both indices are nearly zero. Moreover, the PACF after the lag 1 to

Table 4 The results of Autocorrelation test for return series of S\&P BSE 500. Source: Compiled from Eviews7

\begin{tabular}{|c|c|c|c|c|c|c|}
\hline Autocorrelation & Partial Correlation & & $\mathrm{AC}$ & PAC & Q-Stat & Prob \\
\hline.$|* * *|$ &.$|* * *|$ & 1 & 0.420 & 0.420 & 21.491 & 0.000 \\
\hline .I. I & $* *||$. & 2 & -0.046 & -0.270 & 21.753 & 0.000 \\
\hline .1 .1 &.$|*|$ & 3 & -0.057 & 0.105 & 22.162 & 0.000 \\
\hline$* 1.1$ & $*||$. & 4 & -0.077 & -0.138 & 22.911 & 0.000 \\
\hline .I. I & .l. 1 & 5 & -0.051 & 0.052 & 23.241 & 0.000 \\
\hline .I. I & .1 .1 & 6 & 0.038 & 0.028 & 23.427 & 0.001 \\
\hline.$|*|$ &.$|*|$ & 7 & 0.103 & 0.078 & 24.789 & 0.001 \\
\hline .I. I & .l. I & 8 & 0.038 & -0.054 & 24.977 & 0.002 \\
\hline .I. I & .1 .1 & 9 & -0.047 & -0.023 & 25.272 & 0.003 \\
\hline .I. I & .l. I & 10 & -0.017 & 0.034 & 25.308 & 0.005 \\
\hline$*||$. & $* *||$. & 11 & -0.149 & -0.221 & 28.273 & 0.003 \\
\hline$* *||$. & $*||$. & 12 & -0.242 & -0.077 & 36.123 & 0.000 \\
\hline$*||$. & .1 .1 & 13 & -0.128 & -0.043 & 38.365 & 0.000 \\
\hline .I. I & .l. I & 14 & -0.004 & 0.016 & 38.367 & 0.000 \\
\hline .1 .1 & .1 .1 & 15 & 0.013 & -0.039 & 38.390 & 0.001 \\
\hline .I. I & $*||$. & 16 & -0.049 & -0.076 & 38.723 & 0.001 \\
\hline
\end{tabular}


Table 5 The results of Autocorrelation test for return series of NIFTY 500. Source: Compiled from Eviews7

\begin{tabular}{|c|c|c|c|c|c|c|}
\hline Autocorrelation & Partial Correlation & & $\mathrm{AC}$ & PAC & Q-Stat & Prob \\
\hline.$|* * *|$ &.$|* * *|$ & 1 & 0.422 & 0.422 & 21.733 & 0.000 \\
\hline .1 .1 & $* *||$. & 2 & -0.050 & -0.278 & 22.041 & 0.000 \\
\hline .1 .1 &.$|*|$ & 3 & -0.060 & 0.111 & 22.483 & 0.000 \\
\hline$* \mid$ *l & $* 1.1$ & 4 & -0.076 & -0.141 & 23.206 & 0.000 \\
\hline .1 .1 & .1 .1 & 5 & -0.049 & 0.057 & 23.505 & 0.000 \\
\hline .1 .1 & .1 .1 & 6 & 0.042 & 0.029 & 23.735 & 0.001 \\
\hline.$|*|$ &.$|*|$ & 7 & 0.104 & 0.077 & 25.131 & 0.001 \\
\hline .1 .1 & .1 .1 & 8 & 0.036 & -0.056 & 25.300 & 0.001 \\
\hline .1 .1 & .1 .1 & 9 & -0.049 & -0.021 & 25.613 & 0.002 \\
\hline .1 .1 & .1 .1 & 10 & -0.026 & 0.022 & 25.702 & 0.004 \\
\hline$* \mid .1$ & $* * 1.1$ & 11 & -0.149 & -0.209 & 28.649 & 0.003 \\
\hline$* *||$. & $* 1.1$ & 12 & -0.238 & -0.084 & 36.295 & 0.000 \\
\hline$* \mid$. I & .1 .1 & 13 & -0.128 & -0.040 & 38.530 & 0.000 \\
\hline .1 .1 & .1 .1 & 14 & -0.002 & 0.014 & 38.531 & 0.000 \\
\hline .1 .1 & .1 .1 & 15 & 0.016 & -0.034 & 38.567 & 0.001 \\
\hline .1. 1 & $* 1.1$ & 16 & -0.048 & -0.078 & 38.886 & 0.001 \\
\hline
\end{tabular}

lag 16 coefficients values of both indices are adjacent zero. Hence, the Correlogram clearly corroborate the stationarity in the series.

Month-wise descriptive statistics of S\&P BSE 500 and NIFTY 500 indices return series were presented in Table 6

As can be observed in Table 6, the maximum average (or mean return) occurred in July, and the lowest returns occurred in March for both indices. These results suggest that among the trading month of the year, mean returns for all the months were having different returns distributions. Therefore, $H_{02}$ (the monthly mean returns are statistically equal across the trading month of the year) is rejected. The standard deviation of returns series was greater in March when compared to other months for both the indices. These results indicate that volatility in stock was maximum in March. From intraday trader standpoint, these results suggest that March is an appropriate month. The value of Skewness returns distribution is found to be negative for all the months of the year except February, June and December. The monthly trading returns are asymmetrical distributions. The values of Kurtosis are less than three for all the months of the year except March, October and December for both the indices. It represents that return distribution for the months of the year shows platykurtic curve. The coefficient value of the Jarque-Bera test statistic is insignificant for all the month of the year except March and October. It evident that the month-wise average returns distribution follows the normal distribution. 


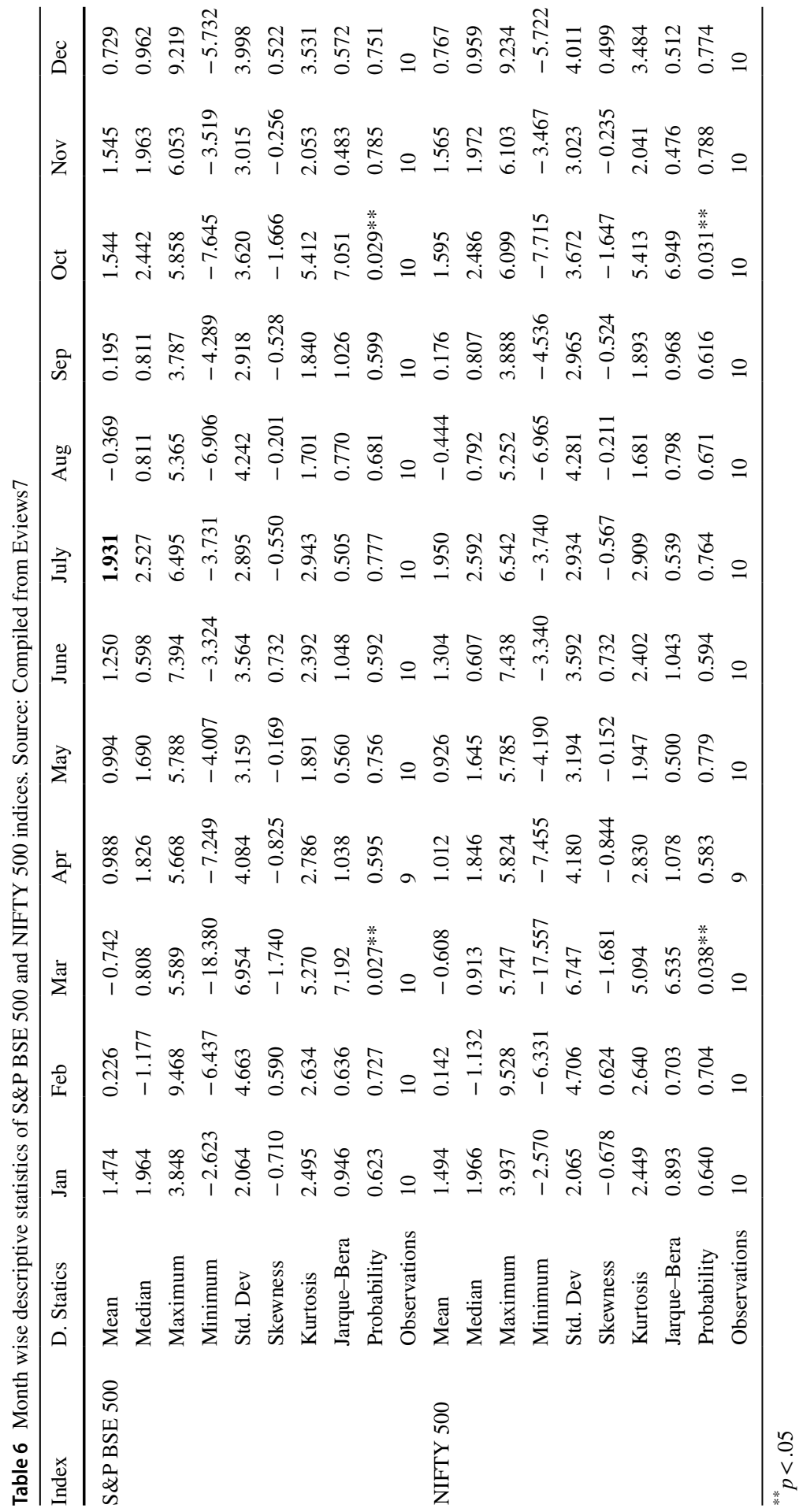




\subsection{OLS Dummy Variable Regression Equation Model}

The descriptive statistics from the study reveal that there is no strong evidence of the month-of-the-year effect of both indices. Therefore, we wanted to identify the month-of-the-year effect by using the Ordinary Least Square (OLS). The regression equation used to find the month of the year effect is as follows:

$$
\begin{aligned}
Y t= & \alpha_{1}+\alpha_{2 D} F e b+\alpha_{3 D} M a r+\alpha_{4 D} A p r+\alpha_{5 D} M a y+\alpha_{6 D} J u n+\alpha_{7 D} J u l \\
& +\alpha_{8 D} A u g+\alpha_{9 D} S e p+\alpha_{10 D} \text { Oct }+\alpha_{11 D} \text { Nov }+\alpha_{12 D} D e c+\varepsilon_{1}
\end{aligned}
$$

The dummy variables for February, March, April, May, June, July, August, September, October, November and December were included in the regression equation. For each dummy variable, the value ' 1 ' represents the corresponding month and 0 represents the rest of the months. Since majority of previous studies reported January effect in the stock market, the monthly average mean returns of January taken as 'Yardstick month' for comparing returns of other trading months for both indices.

The results of the OLS dummy variable regression model of the month-of-theyear effect for S\&P BSE 500 and NIFTY 500 indices were presented in Table 7.

As can be seen in Table 7, the regression coefficients of February, March, April, May, June, August, September and December are negative but insignificant for both indices. The regression coefficient for January, July, October and November are positive but not significant for both indices. The Adjusted R-square is negative for both indices. Moreover, the F.statistic was very low with the p-value. These results indicate that the OLS dummy variable regression model spurious. i.e., the OLS dummy variable regression model does not indicate the month-of-the-year effect. Besides,

Table 7 The results of the OLS dummy variable regression model of the month-of-the year effect for S\&P BSE 500 and NIFTY 500 indices. Source: Compiled from EViews7

\begin{tabular}{lll}
\hline Variables & S\&P BSE 500 & NIFTY 500 \\
\hline January (C) & $1.474(1.182)$ & $1.494(1.197)$ \\
February & $--1.248(-0.708)$ & $-1.352(-0.766)$ \\
March & $-2.216(-1.257)$ & $-2.101(-1.191)$ \\
April & $-0.486(-0.268)$ & $-0.481(-0.266)$ \\
May & $-0.480(-0.272)$ & $-0.568(-0.322)$ \\
June & $-0.225(-0.127)$ & $-0.190(-0.107)$ \\
July & $0.456(0.259)$ & $0.456(0.259)$ \\
August & $-1.843(-1.045)$ & $-1.938(-1.099)$ \\
September & $-1.279(-0.725)$ & $-1.318(-0.747)$ \\
October & $0.070(0.040)$ & $0.101(0.057)$ \\
November & $0.071(0.040)$ & $0.071(0.040)$ \\
December & $-0.745(-0.422)$ & $-0.727(-0.412)$ \\
Adj. ${ }^{2}$ & -0.055 & -0.054 \\
$F-$ Stat & 0.442 & 0.449 \\
$D-W$ Stat & 1.104 & 1.101 \\
AIC & 5.678 & 5.678 \\
SBC & 5.958 & 5.958 \\
\hline
\end{tabular}


the Durbin-Watson statistics values for both indices are less than the acceptable value of two, indicating the existence of serial correlation in this model. To confirm the serial correlation, we applied the Breusch-Godfrey LM test to the OLS dummy variable regression results.

It should be noted that when serial correlation is present, it is necessary to test it further by conducting the Breusch-Godfrey Lagrange-Multiplier (LM). In general, the LM-test is conducted before and after ARIMA, which is consistent with the procedures by the previous researchers. The results of LM-test statistics before and after ARIMA modelling of the month-of-the-year effect in S\&P BSE 500 and NIFTY 500 indices were presented in Table 8.

As can be seen in Table 8, the LM test value before ARIMA for both indices had a very high value $(p<0.000)$, indicating strong evidence for the existence of serial correlation. Since serial correlation in the time series data was confirmed, removing the serial correlation by employing appropriate ARIMA is essential.

Following the Box-Jenkins methodology, we added the appropriate ARIMA terms to the equation for both indices to remove the persistence of serial correlation. After the inclusion of ARIMA terms in the OLS dummy variable regression equation, the Breusch-Godfrey LM test value for S\&P BSE 500 decreased from 30.035 $(p<0.000)$ to $0.643(p=0.725)$; and Breusch-Godfrey LM test value for NIFTY 500 decreased from $30.688(p<0.000)$ to $0.602(p=0.740)$. That means after inclusion, the appropriate AR and MA terms in the equation serial correlation have been removed.

Following the previous researchers, we used GARCH model in this study. The Auto Regressive Conditionally Heteroskedastic (ARCH) is the most frequently used volatility models by the researchers in the field of finance. The basic model consists of equations bout (i) conditional mean, and (ii) conditional variance of the error term (of conditional mean).

The conditional variance equation is:

$$
\sigma_{t}^{2}=\beta_{0}+\beta_{1} \mu_{t-1}^{2}
$$

where $\sigma_{\mathrm{t}}^{2}=$ conditional variance of the error term.

$\mu^{2}{ }_{\mathrm{t}-1}=$ lagged error square term.

The Generalized Auto Regressive Conditionally Heteroskedastic (GARCH) is used (called GARCH $(1,1)$ is employed where the conditional variance is expressed in the following equation:

Table 8 The results of LM-test statistics before and after Arima modelling of the month-of-the-year effect in S\&P BSE 500 and NIFTY 500 indices. Source: Compiled from EViews7

\begin{tabular}{llllllll}
\hline Indices & \multicolumn{2}{l}{ Before ARIMA } & & \multicolumn{2}{l}{ After ARIMA } & & \\
\cline { 2 - 3 } \cline { 6 - 8 } & LM-TEST & P-Value & & AR Terms & MA Terms & LM-TEST & P-Value \\
\hline S\&P BSE 500 & 30.035 & 0.000 & & 1 & 1 & 0.643 & 0.725 \\
NIFTY 500 & 30.688 & 0.000 & & 1 & 1 & 0.602 & 0.740 \\
\hline
\end{tabular}




$$
\sigma_{t}^{2}=\beta_{0}+\beta_{1} \mu_{t-1}^{2}+\gamma \sigma_{t-1}^{2}
$$

It can be observed that the lagged value of the error term and its own lagged value determines the conditional variance of the error term. A higher order GARCH $(p, q)$ which includes 'p' terms of squared own lags, and 'q' terms of squared error terms, is rarely used in the finance literature (Brooks, 2019).

The results of GARCH Model in S\&P BSE 500 and NSE NIFTY 500 indices for month-of-the-year effect were presented in Table 9.

As can be seen in Table 9, the summarized estimates viz., the coefficients of the different trading months of the year, z-Statistic (shown in parentheses), adjusted R-square, Akaike Info Criterion (AIC), and Schwarz Criterion (SBC). The regression coefficients for February, March, April, August, September, October, December were negative but insignificant for both indices. The regression coefficients of November were negative and insignificant for the NIFTY 500 Index alone. However, the regression coefficients for March are negative and significant for both indices. On the other hand, the regression coefficients for January, May, June, July and (November only for S\&P BSE 500) are positive but not significant for the index. It is exciting to note that the month-of-the-year effect was negative and significant only for March for both indices. Therefore, the results document that the month-of-theyear effect is the 'March effect.'

Table 9 The Results of GARCH Model in S\&P BSE 500 and NIFTY 500 indices for monthof-the-year effect. Source: Compiled from EViews7

\begin{tabular}{lll}
\hline Variables & S\&P BSE 500 & NIFTY 500 \\
\hline January (C) & $1.653(1.133)$ & $1.466(1.025)$ \\
February & $-1.563(-1.259)$ & $-1.374(-1.107)$ \\
March & $-3.042(-1.837) * *$ & $-3.001(-1.817) * *$ \\
April & $-0.407(-0.159)$ & $-0.163(-0.067)$ \\
May & $0.033(0.015)$ & $0.368(0.166)$ \\
June & $0.105(0.055)$ & $0.325(0.169)$ \\
July & $0.527(0.242)$ & $0.482(0.218)$ \\
August & $-1.857(-0.958)$ & $-2.139(-1.074)$ \\
September & $-1.507(-0.788)$ & $-1.347(-0.708)$ \\
October & $-0.076(-0.037)$ & $-0.117(-0.056)$ \\
November & $0.011(0.005)$ & $-0.123(-0.061)$ \\
December & $-0.780(-0.512)$ & $-0.694(-0.479)$ \\
Adj. $R^{2}$ & 0.207 & 0.212 \\
$A I C$ & 5.407 & 5.373 \\
$S B C$ & 5.806 & 5.772 \\
\hline${ }^{* *} p<.01$ & &
\end{tabular}




\section{Discussion}

Consistent with the previous researchers, the findings of the study reveal that the ADF and PP test confirms the unit root of the return series of S\&P BSE 500 and NIFTY 500 Indices. Likewise, the KPSS test confirms the stationarity of the return series of both indices. Moreover, the graphical analysis and correlogram of the study also demonstrate the stationarity of the return series of both Indices.

The maximum average or mean return occurred in July for both indices. The lowest returns occurred in March for both indices. These results indicate that among the trading months of the year, mean returns for all the months were different returns distributions. The standard deviation of the returns series occurred maximum in March for both indices. The series found that utmost volatility occurred during March. It is suggested that for intraday traders, March month is an appropriate month. The coefficient value of the Jarque-Bera test statistic is insignificant for all the months of the year except March and October. It is evident that the month-wise average returns distribution follows the normal distribution. The regression coefficients for March were negatively significant for both indices. It is exciting to note that the month-of-the-year effect was negatively significant only during March for both indices. Therefore, the results document that the month-of-the-year effect is the 'March effect.'

\subsection{Explanation to the March Effect}

The objective of the present study is to empirically examine the evidence of monthly seasonality in the Indian stock market during 2011 and 2021. We tested the seasonality using standard methods-testing the stationarity, kurtosis, and volatility clustering- and found that the returns showed high volatility during March. In one of the recent studies conducted in India, Harshita et al. (2018) reported significant volatility in November because of the Diwali effect. Surprisingly, we did not find the November (Diwali effect) effect in our study.

In India, the Union Finance Minister announces the budget every year at the end of February. The budget effect can be found in the prices of goods and services, and the stock market is not an exception. Now, the fundamental question remains whether the presence of the March effect signifies market inefficiency. As Brooks (2019) contends, if investment brokers cannot employ seasonality in their investment strategy, it would not be considered market inefficiency. However, some scholars argue that intelligent investors can still profit from the seasonal fluctuations (Beyer et al., 2013; Chen \& Singhal, 2003; Jaisinghani, 2016). As the results indicated that significant volatility occurred in March from 2011 to 2021, it is necessary to identify the reasons or causes for the March effect. Digging up literature, various reasons were identified for results in other months. These are tax-loss selling hypothesis (Johnston \& Cox, 1996; Ligon, 1997; Sias \& Starks, 1997), tax-gain selling hypothesis for December month (Chen \& Singal, 2003), information hypothesis (Gultekin \& Gultekin, 1983), portfolio rebalancing hypothesis (Beyer et al., 2013), 
liquidity hypothesis (Sharma \& Narayan, 2014), optimistic expectations hypothesis (Barone, 1990).

Our results indicate the budget effect (March effect). The budget presented by Union Finance Minister plays a critical role in influencing the cost-of-living index, consumer price index, and prices in stock markets. The annual budget announced by Union Finance Minister gives information about the proposed government spending and income and sectoral allocation of funds in the coming year. The budget announcement about annual financial of estimated revenues and expenditures of the government for a fiscal year (which runs from 1st April to 31st March) provides not only the "quantity (in terms of money to be spent and taxes on various commodities) but 'quality (which is reflected in terms of macroeconomic impact on the country) of information that is received and digested by population significantly impact the consumer behavior and investor behavior. To minimize risk and maximize returns, investors pay close attention to the budget announcements. Several studies were conducted to see the reaction of policy announcements such as budget, natural disasters such as floods, elections, and change of leadership at the Parliament on stock prices (Kaur, 2004). Some studies predominantly focused on the impact of union budget on stock prices and found that budget announcements resulted in volatility in stock prices (Gupta \& Kundu, 2006; Singhvi, 2014). For example, in one study conducted by Varadharajan and Vikkraman (2011), the findings indicated that volatility in the stock market was higher in the post-budget month when compared to the prebudget month. Other studies by Kutchu (2012) and Babu and Venkateswarlu (2013) also supported the findings of earlier researchers about the effect of the budget on the stock market. The results from our study corroborate the earlier findings of the budget effect on the stock market. Though we did not study specifically the effect of the budget on stock prices, the plausible explanation for the March effect could be linked to the Union budget announcement.

One very interesting finding from our study is the March effect, which is in a sharp contract to some of the earlier studies conducted during June1999- September 2015, that found November effect (Harshita et al., 2018). We were also surprised to see that there was no Diwali effect in our study period (2011 to 2021), though the Diwali effect which comes normally in the month of November. The logical explanation for the lack of Diwali effect (during November) is that the investors expect the stock prices to deviate from the ordinary course. As such, the information gets factored into the current prices. Therefore, it is not abnormal not to have a Diwali effect.

One plausible explanation for the negative deviation in March effect, which comes immediately after the budget announcement, could be in terms of pessimistic behavior of investors. Second, India being one of the largest democratic countries, the sentiments of the investors reflect the conditions in the stock market, and political factors could be factored into the equation. Though it is very difficult to explain how and why political influences would hold, investors expect growth in the economy and when they see that the growth is less than expected, the sentiments get reflected in the stock market. It is also equally possible to have positive deviation in the March effect, provided the investors are optimistic about the rate of growth in 
the economy. Thus, the macroeconomic factors combined with the political influences affect the stock market anomalies, especially in Indian context.

We need to explain that when the budget is declared on 1st February every year, why could we not find the February effect? Up to 2016, the finance minister presented the budget on the last working day of February. Since 2016, the budget was presented on the 1st February in the parliament around $11 \mathrm{am}$, and there is hardly any time for the investors to assimilate information, interpret and react (businessinsider.in, 2021). Therefore, from 2011 to 2016, the budget effect was reflected in March every year. However, from 2016 to 2021, though the budget was presented on 1st February, the influence was felt only in March. It would be logical to assume that it takes at least some days to gather complete information and infer the effects of the budget on the economy. This information may be reflected in March (when we see the month-of-the-year effect). Our results support this assumption that investors take time to evaluate the budget and react to it, and hence the results are not contrary to the expectation.

\subsection{Contributions of the Present Study}

Despite several studies conducted about the calendar anomalies (month-of-the-year effect) by various scholars, the present study was conducted to analyze the stock market anomalies during the decade 2011-2011. The results from the study have several contributions to both the literature on finance and practicing managers. First, the study highlights the importance of studying the month-of-the-year effect during the fascinating period that has changed political power (shifting of power from the Congress to Bharatiya Janata Party in 2014), which may profoundly influence the stock market. Though we did not study the effect of change in political power, we wanted to see whether there is any month-of-year effect during this crucial period. One significant contribution of the results from the study is that throughout the ten years, the 'March effect ' was pronounced, implying that change in political power did not have any impact on the month-of-the-year effect.

Second, the results show that contrary to the previous studies that documented the November effect (Harshita et al., 2018), December effect (Choithala \& Ajmal, 2016), January effect (Sudarvel \& Velmurugan, 2015), and February, August, and September (Debasish, 2012), our results showed March effect during the present decade (2011-2021). The study periods were, however, different from the previous studies.

Third, our results provide statistical evidence for the abnormal returns during March of every year during the study period. The results also suggest the investors be mindful of the March effect in subsequent years (2021 onwards). It is also astonishing to notice that the March effect was also pronounced even during the global pandemic COVID-19. Though the world economy was hard-hit by the pandemic, the Indian economy is not an exception, as stock prices have become highly volatile and showed a somewhat downward return trend. Finally, as the countries are coming back to normal, the stock market is expected to return to normal in the years to come. 


\subsection{Suggestions for Future Research}

The present study provides several avenues for future research. First, future researchers may study the pre-budget and post-budget effects on the stock market over the last ten years (from 2011-2021) and see whether the effect is significant one week or two weeks before implementing the budget (during April). However, insider information about budget announcements may also have some impact on stock prices. In a democratic country, it is not impossible to get inside information before the announcement of the budget by the Union Minister. Second, future researchers can make international comparisons (by comparing the stock markets in developing countries such as Pakistan and Bangladesh) to see whether the March effect is present in those comparable countries. Third, future research can focus on the differences in stock market volatility due to global disturbances (for example, COVID global pandemic) at the international level. In the present study, the last year (the year 2020) fell under the worldwide pandemic's grip and showed some deep dip; future researchers can see how the drop was for different countries. However, international comparisons were outside the scope of the present research.

\subsection{Conclusion}

The findings of the study disclose the regression coefficients for March are negatively significant for both indices. It is fascinating to note that the month-of-the-year effect was negatively significant only during March for both indices. Therefore, the results document that the month-of-the-year effect is the 'March effect.' The results suggest that investment brokers and organizations take into account the March effect while making strategic financial and investment decisions. Since the investment climate has undergone paradigmatic change during the COVID global pandemic, it would be interesting to examine the post-pandemic effect on the stock market. It also would be interesting to see whether the history gets repeated after the pandemic about a century ago in the world, where most of the countries had suffered. However, the stock market was not that robust. With the increase in technology and resilience strategies of global companies to turn around and bounce back, it would be interesting to see how investors react during the post-pandemic era. Despite the setbacks, we hope the stock market bounces back and assumes normality. The interest in studying stock market anomalies continues to remain on the agenda of research in the field of finance and economics.

\section{References}

Abedin, M. Z., Chi, G., \& Bin, M. (2015). The month of the year effect on dhaka stock exchange. International Journal of u-and e-Service Science and Technology, 8(5), 275-288.

Adinya, I., Oke, T., \& Edeki, S. O. (2019). Analysis of month-of-the-year effect in an emerging market via stochastic dominance approach. Academy of Entrepreneurship Journal, 25(2), 1-6.

Aggarwal, R., \& Rivoli, P. (1989). Seasonal and day-of-the-week effects in four emerging stock markets. The Financial Review, 24(4), 541-550. 
Agrawal, A., \& Tandon, K. (1994). Anomalies or illusions? Evidence from stock market in eighteen countries. Journal of International Money and Finance, 13(1), 83-106.

Alagidede, P. (2013). Month of the year and pre-holiday effects in African stock markets. South African Journal of Economic and Management Sciences, 16(1), 64-74.

Albert, L., Ida, L. A., \& Nasiru, S. (2013). Calendar anomalies in treasury bills rate in ghana. International Journal of Finance and Accounting, 2(8), 417-421.

Angelovska, J. (2014). Month related seasonality on the macedonian stock market. Business and Economics Research Journal, 5(1), 143-150.

Arendas, P., \& Kotlebova, J. (2019). The turn of the month effect on CEE stock markets. International Journal of Financial Studies, 7(4), 1-19.

Asteriou, D., \& Kavetsos, G. (2006). Testing for the existence of the 'January effect' in transition economies. Applied Financial Economics Letters, 2(6), 375-381.

Babu, S. S., \& Venkateswarlu, M. (2013). Impact of Union Budget on Indian Stock Prices. International Journal of Management Research and Review, 3(5), 2890-2896.

Barone, E. (1990). The Italian stock market: Efficiency and calendar anomalies. Journal of Banking and Finance, 14(2-3), 483-510.

Berges, A., McConnell, J. J., \& Schlarbaum, G. G. (1984). The turn-of-the-year in Canada. Journal of Finance, 39(1), 185-192.

Beyer, S., Garcia-Feijoo, L., \& Jensen, G. R. (2013). Can you capitalize on the turn-of-the-year effect? Applied Financial Economics, 23(18), 1457-1468.

Boudreaux, D. O. (1995). The monthly effect in international stock markets: Evidence and implications. Journal of Financial and Strategic Decisions, 8(1), 15-20.

Brooks, C. (2019). Introductory Econometrics for Finance. Cambridge University Press.

Brown, P., Keim, D., Kleidon, A., \& Marsh, T. (1983). New evidence on the nature of size-related anomalies in stock prices. Journal of Financial Economics, 12(1), 33-56.

businessinsider.in (2021). https://www.businessinsider.in/budget/news/nirmala-sithraman-union-budget2021-date-time-schedule-and-other-details-you-should-know/articleshow/80598178.cms

Chandra, A. (2009). Stock market anomalies: A survey of calendar Effect in BSE-SENSEX. Indian Journal of Finance, 5(5), 1-5.

Chen, H., \& Singal, V. (2003). Role of speculative short sales in price formation: Case of the weekend effect. Journal of Finance, 58(2), 685-705.

Cheung, K. C., \& Coutts, J. A. (1999). The January effect and monthly seasonality in the Hang Seng index: 1985-97. Applied Economics Letters, 6(2), 121-123.

Choithala, F., \& Ajmal, T. K. (2016). December volatility of indian stock market with the special reference of bombay stock exchange. International Journal of Business Quantitative Economics and Applied Management Research, 3(7), 19-24.

Ciccone, S. J., \& Etebari, A. (2008). A month-by-month examination of long-term stock returns. Investment Management and Financial Innovation, 5(3), 8-18.

Compton, W., Kunkel, R. A., \& Kuhlemeyer, G. (2013). Calendar anomalies in Russian stocks and bonds. Managerial Finance, 39(12), 1138-1154.

Cross, F. (1973). The behavior of stock prices on Fridays and Mondays. Financial Analysts Journal, 29(November), 67-69.

Darrat, A. F., Li, B., \& Chung, R. (2013). Seasonal anomalies: A closer look at the johannesburg stock exchange. Contemporary Management Research, 9(2), 155-168.

Debasish, S. S. (2012). An empirical study on month of the year effect in gas oil and refineries sectors in indian stock market. International Journal of Management and Strategy, 3(5), 1-18.

Deepak, R., \& Viswanath, N. S. (2012). Seasonality and sensitivity of NSE NIFTY-An econometric analysis. International Journal of Research in Management Economics and Commerce, 2(11), 202-224.

Easterday, K. E., Sen, P. K., \& Stephan, J. A. (2009). The persistence of the small firm/January effect: Is it consistent with investors' learning and arbitrage efforts? The Quarterly Review of Economics and Finance, 49(3), 1172-1193.

Fama, E. F. (1970). Efficient capital markets: A review of theory and empirical work. The Journal of Finance, 25(2), 383-417.

Fields, M. J. (1931). Stock prices: A problem in verification. Journal of Business, 4, 415-418.

Floros, C. (2011). On the relationship between weather and stock market returns. Studies in Economics and Finance, 28(1), 5-13.

French, K. R. (1980). Stock returns and the weekend effect. Journal of Financial Economics, 8, 55-70. 
Gao, L., \& Kling, G. (2005). Calendar effects in Chinese stock market. Annals of Economics and Finance, $6(1), 75-88$.

Gultekin, M., \& Gultekin, B. (1983). Stock market seasonality: International evidence. Journal of Financial Economics, 12, 469-481.

Gupta, A., \& Kundu, D. (2006). A study of the impact of union budgets on stock prices in India. The ICFAI Journal of Applied Finance, 12(10), 65-76.

Hafeez, B., Hassan, T. R., Habib, A., \& Sabir, N. (2014). Stock market anomalies across various stock market indices of Pakistan. International SAMANM Journal of Finance and Accounting, 2(2), 192-208.

Haroon, M. A., \& Shah, N. (2013). Investigating day-of-the-week effect in stock returns: Evidence from Karachi Stock Exchange-Pakistan. Pakistan Journal of Commerce and Social Sciences, 7(2), 381-393.

Harshita, H., Singh, S., \& Yadav, S. S. (2018). Calendar anomaly: Unique evidence from the Indian stock market. Journal of Advances in Management Research, 15(1), 87-108.

Ivanovski, Z., Narasanov, Z., \& Ivanovska, N. (2015). Volatility and kurtosis at emerging markets: Comparative analysis of macedonian stock exchange and six stock markets from Central and Eastern Europe. Journal of International Scientific Publication, Economy and Business, 9(1), 84-93.

Jacobs, B. I., \& Levy, K. N. (1988). Disentangling equity return regularities: New insights and investment opportunities. Financial Analysts Journal, 44(3), 18-43.

Jaisinghani, D. (2016). An empirical test of calendar anomalies for the Indian securities markets. South Asian Journal of Global Business Research, l, 5, 53-84.

Johnston, K., \& Cox, D. R. (1996). The influence of tax-loss selling by individual investors in explaining the January effect. Quarterly Journal of Business and Economics, 35(2), 14-20.

Jones, S. L., Lee, W., \& Apenbrink, R. (1991). New evidence on the january effect before personal income taxes. Journal of Finance, 46(5), 1909-1924.

Kaur, H. (2004). Stock market volatility in India. The Indian Journal of Commerce, 57(4), 55-70.

Keim, D. B. (1983). Size-related anomalies and stock return seasonality: Further empirical evidence. Journal of Financial Economics, 12(1), 13-32.

Khan, M. S., \& Khan, A. (2014). Calendar anomalies, reality or an illusion? KSE-Pakistan. Journal of Economics and International Finance, 6(4), 80-84.

Kumar, H., \& Dawar, M. (2017). Seasonality in the Indian stock markets: A study of calendar effects. MUDRA: Journal of Finance and Accounting, 4(1), 1-19.

Kumari, G. L., \& Uthra, V. (2018). an analysis of turn of the month effect on S\&P BSE healthcare index in the Indian stock market. International Journal of Trend in Scientific Research and Development, 2(2), 138-145.

Kuria, A. M., \& Riro, G. K. (2013). Stock market anomalies: A study of seasonal effects on average returns of Nairobi securities exchange. Research Journal of Finance and Accounting, 4(7), 207-215.

Kushwah, S. V., \& Munshi, M. S. (2018). The effect of seasonality over stock exchanges in India. Amity Journal of Management, 4(2), 46-53.

Kutchu, V. (2012). Testing semi-strong efficiency of indian stock market - a study on effect of union budget 2012 on six select sectoral stocks. International Refereed Research Journal, 3(2), 74-78.

Li, B., \& Liu, B. (2010). Monthly seasonality in the New Zealand stock market. International Journal of Business Management and Economic Research, 1(1), 9-14.

Ligon, J. A. (1997). A simultaneous test of competing theories regarding the January effect. The Journal of Financial Research, 20(1), 13-32.

Lodha, S., \& Soral, G. (2015). Seasonal Patterns in Indian Stock Markets: An Application of GARCH (1, 1) Model: American International Journal of Research in Humanities. Arts and Social Sciences, 9(1), 33-43.

Luo, J., Gan, C., Hu, B., \& Kao, T. K. (2009). An empirical analysis of Chinese stock price anomalies and volatility. Investment Management and Financial Innovations, 6(1), 199-216.

Malkiel, B. G. (2003). The efficient market hypothesis and its critics. Journal of Economic Perspectives, 17(1), 59-82.

Merton, R. C. (1987). On the current state of the stock market rationality hypothesis, in Macroeconomics and Finance: Essays in Honor of Franco Modigliani. In R. Dornbusch \& S. Fischer (Eds.), MIT Press. Cambridge: Mass.

Nageswari, P., Selvam, M., Vanitha, S., \& Babu, M. (2013). An empirical analysis of january anomaly in the indian stock market. International Journal of Accounting and Financial Management Research, 3(1), $177-186$.

Neeraja, P., \& Srikanth, C. P. (2014). Anomalies in Indian stock market-an empirical evidence from seasonality effect on BSEIT index. Researchers World, 5(3), 109-116. 
Patel, J. B. (2008). Calendar effects in the Indian stock market. International Business and Economics Research Journal, 7(3), 61-70.

Patel, J. B. (2014). The monthly barometer of the indian stock market. International Business and Economics Research Journal, 13(1), 85-92.

Patel, N., \& Sewell, M. (2015). Calendar anomalies: A survey of the literature. International Journal of Behavioural Accounting and Finance, 5(2), 99-121.

Pathak, M. R. (2013). Stock market seasonality: A study of the Indian stock market (NSE). Paripex-Indian Journal of Research, 2(3), 200-202.

Pettengill, G. N. (1986). A non-tax cause for the January effect? Evidence from Early Data. Quarterly Journal of Business and Economics, 25(3), 15-33.

Raharjo, A., Mabaraq, F., \& Mundir, F. (2013). December effect of stock market return in Indonesia Stock Exchange 1998-2012. International Journal of Science and Research, 2(1), 708-711.

Rengasamy, E., \& Pandey, D. (2008). An empirical study on January anomaly and return predictability in an emerging market: Evidence from India. SSRN Electronic Journal. https://doi.org/10.2139/ssrn.1150080

Rompotis, G. (2009). A comprehensive study on the seasonality of Greek equity funds performance. SouthEastern Europe Journal of Economics, 7(2), 229-255.

Rozeff, M. S., \& Kinney, W. R. (1976). Capital market seasonality: The case of stock returns. Journal of Financial Economics, 3, 379-402.

Schultz, P. (1985). Personal income taxes and the January effect: Small firm stock returns before the war revenue act of 1917. Journal of Finance, 40, 333-343.

Sharma, S. S., \& Narayan, P. K. (2014). New evidence on turn-of-the-month effects. Journal of International Financial Markets, Institutions \& Money, 29(1), 92-108.

Sias, R. W., \& Starks, L. T. (1997). Institutions and individuals at the turn-of-the-year. The Journal of Finance, 52(4), 1543-1562.

Silva, P. M. (2010). Calendar "anomalies" in the Portuguese stock market. Investment Analysts Journal, $39(71), 37-50$.

Simbolon, I. P. (2015). January effect of stock returns in Indonesia: The unconditional method and the conditional method. International Business Management, 9(6), 1221-1225.

Singhvi, A. (2014). Impact of union budget on NIFTY. Pacific Business Review International, 6(12), $23-28$.

Srinivasan, P., \& Kalaivani, M. (2013). Day-of-the-week effects in the Indian Stock Market. Munich Personal RePEc Archive (MPRA), 46805, 1-22.

Sriram, M., \& Devi, P. R. (2013). Seasonality in the returns: A study of BSE Sensex. International Journal of Financial Management, 3(1), 60-69.

Sudarvel, J., \& Velmurugan, R. (2015). January effect in indian banking sector with reference to BSE bank index. International Journal of Management Research and Reviews, 5(11), 1066-1071.

Varadharajan, P., \& Vikkraman, P. (2011). Impact of Pre and Post Budget on stock market volatility between 2001 to 2011. Journal of Contemporary Research in Management, 6(4), 49-64.

Verma, A., \& Kumar, C. V. R. S. V. (2012). Month effect in the Bombay stock market. International Journal of Engineering and Management Research, 2(5), 1-9.

Wachtel, S. B. (1942). Certain observations on seasonal movements in stock prices. The Journal of Business of the University of Chicago, 15(2), 184-193.

Wilson, J. W., \& Jones, C. P. (1993). Comparison of seasonal anomalies across major equity markets: A note. The Financial Review, 28(1), 107-115.

Wong, M. K., Ho, C. M., \& Dollery, B. (2007). An empirical analysis of the Monthly Effect: The case of the Malaysian Stock Market. Paper Series in Economic of University of New England.

Yadav S.P. (2013). Calendar Anomaly in Indian Stock Market with Respect to Empirical Study of Quarter of the Year Effect, Month of the Year Effect, Day of the Week Effect on NIFTY for The Years Jan. 1996Mar. 2013: Vishwakarma Business Review, 3 (2):76-85.

Zinbarg, E. D., \& Harrington, J. J. (1964). The stock market's 'seasonal pattern.' Financial Analysts Journal, 20(1), 53-55.

Publisher's Note Springer Nature remains neutral with regard to jurisdictional claims in published maps and institutional affiliations. 